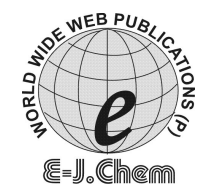

http://www.e-journals.net

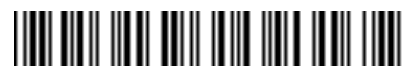

ISSN: 0973-4945; CODEN ECJHAO

E-Journal of Chemistry

Vol. 4, No. 4, pp. 536-545, October 2007

\title{
Analysis of Three Penicillin Antibiotics (Ampicillin, Amoxicillin and Cloxacillin) of Several Iranian Pharmaceutical Companies by HPLC
}

\author{
A. ASHNAGAR,*N. GHARIB NASERI \\ *School of Pharmacy, Ahwaz Jundi Shapour Univ. of Medical Sciences, Ahwaz, Iran. \\ Ahwaz Faculty of Petroleum Engineering, Petroleum Univ. of Technology, Iran. \\ aashnagar2003@yahoo.com
}

Received 4 March 2007; Accepted 30 March 2007

\begin{abstract}
Penicillin has been the most widely used antibiotic for many grampositive bacterial infections. In this research the purity of the standard active ingredients of the various dosage forms of three penicillins (Amoxicillin, Cloxacillin and Ampicillin) imported and the purity percentage of the active ingredients in each of the various dosage forms of these drugs manufactured by several pharmaceutical companies of Iran (Kosar, Farabi and Jaber Ibn Hayan) were investigated and determined by HPLC technique. The analyses were made by using a Knauer (Germany) Spherimage-80, ODS, 2-5 $\mu \mathrm{m} \mathrm{C}_{18}$ column with $30 \mathrm{~cm}$ length, and i.d. $4.5 \mathrm{~mm}$. A $20 \mu \mathrm{L}$ solution from each individual sample and the standard solution were injected separately onto the column of an HPLC instrument which was equipped with ECW 2000 software of Knauer, Germany. The results obtained in this research have shown that the purity percentage of the active ingredients of the standard powder and the various dosage forms of all the drugs used, were $100 \%$.
\end{abstract}

Keywords: Penicillin, Amoxicillin, Cloxicillin, Ampicillin, Antibiotics.

\section{Introduction}

Penicillin (sometimes abbreviated PCN) refers to a group of $\beta$-lactam antibiotics used in the treatment of bacterial infections caused by susceptible, usually gram-positive, organisms. The name "penicillin" can also be used in reference to a specific member of the penicillin group. All penicillins possess the basic Penam Skeleton, which has the molecular formula $\mathrm{R}-\mathrm{C}_{9} \mathrm{H}_{11} \mathrm{~N}_{2} \mathrm{O}_{4} \mathrm{~S}$, where $\mathrm{R}$ is a variable side chain. The chemical structure of penicillin was 
determined by Dorothy Crowfoot Hodgkin in the early 1940s, enabling synthetic production. A team of Oxford research scientists led by Australian Howard Walter Florey and including Ernst Boris Chain and Norman Heatley discovered a method of mass producing the drug. Penicillin has since become the most widely used antibiotic to date and is still used for many Gram-positive bacterial infections ${ }^{1}$.

Ampicillin is a $\beta$-lactam antibiotic that has been used extensively to treat bacterial infections since 1961. It can sometimes result in allergic reactions that range in severity from a rash (i.e. patients with mononucleosis) to potentially lethal anaphylaxis. Belonging to the group of $\beta$-lactam antibiotics, ampicillin is able to penetrate gram-positive and some gram-negative bacteria. It inhibits the third and final stage of bacterial cell wall synthesis, which ultimately leads to cell lysis ${ }^{2}$. Ampicillin is one of the most widely prescribed antibiotics. It is considered a penicillin and is a close relative of another penicillin, amoxicillin. Unlike penicillin, ampicillin and amoxicillin can penetrate and prevent the growth of certain types of bacteria, called gramnegative bacteria. Ampicillin is used mainly to treat infections of the middle ear, sinuses, bladder, kidney, and uncomplicated gonorrhea. It is also used intravenously to treat meningitis and other serious infections ${ }^{3}$. A semisynthetic penicillin having a broader antibacterial spectrum of action than that of penicillin G. It is effective against gram-negative and gram-positive bacteria and used to treat gonorrhea and infections of the intestinal, urinary, and respiratory tracts ${ }^{4}$.

Amoxicillin (INN) or amoxycillin (former BAN) is a moderate-spectrum $\beta$-lactam antibiotic used to treat bacterial infections caused by susceptible microorganisms. It is usually the drug of choice within the class because it is better absorbed, following oral administration, than other $\beta$-lactam antibiotics. Amoxicillin is susceptible to degradation by $\beta$-lactamase-producing bacteria, and so may be given with clavulanic acid to decrease its susceptibility. Amoxicillin acts by inhibiting the synthesis of bacterial cell walls. It inhibits cross-linkage between the linear peptidoglycan polymer chains that make up a major component of the cell wall of gram-positive bacteria ${ }^{5}$.

Cloxacillin is a semisynthetic antibiotic in the same class as penicillin. Cloxacillin is used against staphylococci that produce $\beta$-lactamase. This drug has a weaker antibacterial activity than benzylpencillin, and is devoid of serious toxicity except for allergic reactions ${ }^{6}$.

\section{Experimental}

All the chemicals used were purchased from Merck Company. Ampicillin, amoxicillin and cloxacillin standard powder, 250, $500 \mathrm{mg}$ capsules, 125, $250 \mathrm{mg}$ oral suspensions, 250, 500 and $1000 \mathrm{mg}$ vials were supplied by Jaber Ibn Hayan, Kosar, Farabi Pharmaceutical Companies of Iran and also purchased from pharmaceutical markets in Iran. High Performance Liquid Chromatography analyses were performed on a HPLC (JASCO, Japan, with Liquid Pump 880-PU; UV-Visible detector (870-UV); the instrument was equipped with an Interface (from Knauer company of Germany) and software program ECW2000 version 2.05. Millipore membranes (0.45) made in Germany, $\mathrm{pH}$ meter (Metrohm, 644 Switzerland) and Sartorius 2434 analytical balance (Germany) were used.

\section{Preparation of the solvent for ampicillin solutions}

$1.36 \mathrm{~g}$ potassium dihydrogen phosphate was weighed precisely and transferred into a $10 \mathrm{~mL}$ volumetric flask. Distilled water was added and made the volume by adding more distilled water (i.e $1 \mathrm{M}$ solution was prepared). The whole solution was transferred into a $1000 \mathrm{~mL}$ volumetric flask and $1 \mathrm{~mL} 1 \mathrm{~N}$ acetic acid was added then made the volume to $1000 \mathrm{~mL}$ by adding more distilled water. This solvent was used for the preparation of ampicillin standard and sample solutions. 


\section{Preparation of standard solution of ampicillin $(1 \mathrm{mg} / \mathrm{mL})$}

$100 \mathrm{mg}$ of the ampicillin standard powder was weighed precisely and transferred into a 100 $\mathrm{mL}$ volumetric flask. After dissolving in a few milliliter of the solvent, the volume was made by adding more of the solvent. $25 \mathrm{~mL}$ of this solution was filtered on Millipore filter disc and used for injection into the HPLC instrument.

\section{Preparation of sample solution of ampicillin $(1 \mathrm{mg} / \mathrm{mL})$}

(i) From capsules:

The contents of five capsules of ampicillin $(250 \mathrm{mg} / 500 \mathrm{mg}$ manufactured by Farabi and Kosar pharmaceutical companies) were mixed and weighed precisely then $100 \mathrm{mg}$ of the mixture was transferred into a $100 \mathrm{~mL}$ volumetric flask, and made the volume by adding more of the solvent ( $1 \mathrm{mg} / \mathrm{mL}$ solutions). $25 \mathrm{~mL}$ of this solution was filtered on Millipore filter disc and used for injection into the HPLC instrument.

(ii) From oral suspension:

The contents of ampicillin oral suspension containers $(125 \mathrm{mg} / 5 \mathrm{~mL}$ and $250 \mathrm{mg} / 5 \mathrm{~mL}$ manufactured by Farabi and Kosar pharmaceutical companies) were diluted with the solvent until solutions with concentration of $1 \mathrm{mg} / \mathrm{mL}$ were obtained. $25 \mathrm{~mL}$ of each was further diluted to $100 \mathrm{~mL}(0.25 \mathrm{mg} / \mathrm{mL}$ concentration). These solutions were filtered on Teflon filter discs, the filtrates were used for injection into the HPLC instrument.

(iii) From vials:

$100 \mathrm{mg}$ of the contents of ampicillin vials $(250,500$ and $1000 \mathrm{mg} / \mathrm{mL}$ manufactured by Jaber Ibn Hayan pharmaceutical company) were weighed precisely and transferred into $100 \mathrm{~mL}$ volumetric flask. After dissolving in a few milliliters of the solvent, the volume was made by adding more of the solvent (concentration of $1 \mathrm{mg} / \mathrm{mL}$ were obtained). $25 \mathrm{~mL}$ of each solution was filtered on Teflon filter discs, the filtrates were used for injection into the HPLC instrument.

\section{Preparation of the solvent for amoxicillin solutions}

$1.36 \mathrm{~g}$ potassium dihydrogen phosphate was weighed precisely and transferred into a 100 $\mathrm{mL}$ volumetric flask. Distilled water was added and made the volume by adding more distilled water (i.e. $1 \mathrm{M}$ solution was prepared). To this solution, potassium hydroxide was added until the $\mathrm{pH}=5 \pm 0.1$ was reached. This solvent was used for the preparation of amoxicillin standard and sample solutions.

\section{Preparation of the standard solution of amoxicillin $(1 \mathrm{mg} / \mathrm{mL})$}

$100 \mathrm{mg}$ of the amoxicillin standard powder was weighed precisely and transferred into a $100 \mathrm{~mL}$ volumetric flask. After dissolving in a few milliliter of the solvent, the volume was made by adding more of the solvent. $25 \mathrm{~mL}$ of this solution was filtered on Millipore filter disc and used for injection into the HPLC instrument.

\section{Preparation of the sample solution of amoxicillin $(1 \mathrm{mg} / \mathrm{mL})$}

(i) From capsules:

The contents of 20 capsules of amoxicillin $(250 \mathrm{mg} / 500 \mathrm{mg}$ manufactured by Farabi and Kosar pharmaceutical companies) were mixed and weighed precisely then $200 \mathrm{mg}$ of the mixture was transferred into a $100 \mathrm{~mL}$ volumetric flask, and made the volume by adding 
more of the solvent $5 \mathrm{~mL}$ of this solution was transferred into a $10 \mathrm{~mL}$ volumetric flask and made the volume by adding more of the solvent $(1 \mathrm{mg} / \mathrm{mL}$ solution). The solution was filtered on Millipore filter disc and used for injection into the HPLC instrument.

(ii) From oral suspension:

The contents of Amoxicillin oral suspension containers $(125 \mathrm{mg} / 5 \mathrm{~mL}$ and $250 \mathrm{mg} / 5 \mathrm{~mL}$ manufactured by Farabi and Kosar pharmaceutical companies) were diluted with the solvent until solutions with concentration of $1 \mathrm{mg} / \mathrm{mL}$ were obtained. $25 \mathrm{~mL}$ of each solution was filtered on Teflon filter discs, the filtrates were used for injection into the HPLC instrument.

\section{Preparation of the solvent for cloxacillin solutions}

2.7 g potassium dihydrogen phosphate was weighed precisely and transferred into a $100 \mathrm{~mL}$ volumetric flask. Distilled water was added and made the volume by adding more distilled water. To this solution, potassium hydroxide was added until the $\mathrm{pH}=5 \pm 0.1$ was reached. This solvent was used for the preparation of cloxacillin standard and sample solutions.

\section{Preparation of the standard solution of cloxacillin $(1 \mathrm{mg} / \mathrm{mL})$}

$100 \mathrm{mg}$ of the cloxacillin standard powder was weighed precisely and transferred into a 100 $\mathrm{mL}$ volumetric flask. After dissolving in a few milliliter of the solvent, the volume was made by adding more of the solvent. $25 \mathrm{~mL}$ of this solution was filtered on Millipore filter disc and used for injection into the HPLC instrument.

\section{Preparation of the sample solution of cloxacillin $(1 \mathrm{mg} / \mathrm{mL})$}

(i) From capsules:

The contents of 10 capsules of cloxacillin $(250 \mathrm{mg} / 500 \mathrm{mg}$ manufactured by Farabi and Kosar pharmaceutical companies) were mixed and weighed precisely then $100 \mathrm{mg}$ of the mixture was transferred into a $100 \mathrm{~mL}$ volumetric flask, and made the volume by adding more of the solvent. $25 \mathrm{~mL}$ of the solution was filtered on Millipore filter disc and used for injection into the HPLC instrument.

(ii) From oral suspension $(1 \mathrm{mg} / \mathrm{mL})$ :

The contents of Cloxacillin oral suspension containers $(125 \mathrm{mg} / 5 \mathrm{~mL}$ manufactured by Farabi and Kosar pharmaceutical companies) were diluted with the solvent until solutions with concentration of $1 \mathrm{mg} / \mathrm{mL}$ were obtained. $25 \mathrm{~mL}$ of each solution was filtered on Teflon filter discs, the filtrates were used for injection into the HPLC instrument.

(iii) From vials:

$100 \mathrm{mg}$ of the contents of cloxacillin vials $(250$ and $500 \mathrm{mg} / \mathrm{mL}$ manufactured by Jaber $\mathrm{Ibn}$ Hayan pharmaceutical company) were weighed precisely and transferred into $100 \mathrm{~mL}$ volumetric flask. After dissolving in a few milliliters of the solvent, the volume was made by adding more of the solvent (concentration of $1 \mathrm{mg} / \mathrm{mL}$ were obtained). $25 \mathrm{~mL}$ of each solution was filtered on Teflon filter discs, the filtrates were used for injection into the HPLC instrument.

HPLC optimum conditions used for the analysis of amoxicillin standard powder and other dosage forms

Stationary Phase: Knauer (Germany) Spherimage-80, ODS, 2-5 $\mu \mathrm{m} \mathrm{C}_{18}$ column with $30 \mathrm{~cm}$ length, and i.d. $4.5 \mathrm{~mm}$ 
Mobile Phase: $\quad$ Buffer solution of $\mathrm{KH}_{2} \mathrm{PO}_{4}: \mathrm{CH}_{3} \mathrm{CN}(24: 1 \mathrm{~V} / \mathrm{V})$

Flow rate: $\quad 0.7 \mathrm{~mL} / \mathrm{min}$

Column Temperature: Room temperature

$\lambda_{\max }=230 \mathrm{~nm}$, AUFS $=0.001$

Injected volume: $\quad 20 \mu \mathrm{L}$

Sample concentration: $1 \mathrm{mg} / \mathrm{mL}$

The purity percentages of amoxicillin standard powder and other dosage forms manufactured by the two Iranian pharmaceutical companies are given in Table 1.

Table 1. Comparison of purity of amoxicillin products by HPLC method

\begin{tabular}{cccccc}
\hline No. & Sample & Manufacturer & $\begin{array}{c}\text { Batch } \\
\text { No. }\end{array}$ & $\begin{array}{c}\text { Purity, } \\
\%\end{array}$ & $\begin{array}{c}\text { Impurity, } \\
\%\end{array}$ \\
\hline 1 & Standard powder & Imported & -- & 100 & 0 \\
2 & $500 \mathrm{mg}$ Capsules & Farabi & 932 & 100 & 0 \\
3 & $250 \mathrm{mg}$ Capsules & Farabi & 158 & 100 & 0 \\
4 & $250 \mathrm{mg} / 5 \mathrm{~mL}$ Oral & Farabi & 10514 & 100 & 0 \\
5 & suspension & & & & \\
5 & $125 \mathrm{mg} / 5 \mathrm{~mL}$ Oral & Farabi & 9218 & 100 & 0 \\
6 & suspension & & & & \\
7 & $500 \mathrm{mg}$ Capsules & Kosar & 0105199 & 100 & 0 \\
8 & $250 \mathrm{mg}$ Capsules & Kosar & 0103832 & 100 & 0 \\
9 & suspension & Kosar & 0103257 & 100 & 0 \\
9 & $125 \mathrm{mg} / 5 \mathrm{~mL}$ Oral & Kosar & 0103604 & 100 & 0 \\
\hline
\end{tabular}

HPLC optimum conditions used for the analysis of cloxacillin standard powder and other dosage forms

Stationary Phase: $\quad$ Knauer (Germany) Spherimage-80, ODS, 2-5 $\mu \mathrm{m} \mathrm{C}_{18}$ column with $30 \mathrm{~cm}$ length, and i.d. $4.5 \mathrm{~mm}$

Mobile Phase:

Buffer solution of $\mathrm{KH}_{2} \mathrm{PO}_{4}: \mathrm{CH}_{3} \mathrm{CN}(3: 1 \mathrm{~V} / \mathrm{V})$

Flow rate: $1.5 \mathrm{~mL} / \mathrm{min}$

Column Temperature: $\quad$ Room temperature

$\lambda_{\max }=225 \mathrm{~nm}, \mathrm{AUFS}=0.001$

Injected volume: $\quad 20 \mu \mathrm{L}$

Sample concentration: $1 \mathrm{mg} / \mathrm{mL}$

The purity percentages of cloxacillin standard powder and other dosage forms manufactured by the two Iranian pharmaceutical companies are given in Table 2 .

HPLC optimum conditions used for the analysis of ampicillin standard powder and other dosage forms

Stationary Phase:

Knauer (Germany) Spherimage-80, ODS, 2-5 $\mu \mathrm{m} \mathrm{C}_{18}$ column with $30 \mathrm{~cm}$ length, and i.d. $4.5 \mathrm{~mm}$

Mobile Phase:

Buffer solution of $\mathrm{H}_{2} \mathrm{O}: \mathrm{CH}_{3} \mathrm{CN}: \mathrm{KH}_{2} \mathrm{PO}_{4}: \mathrm{CH}_{3} \mathrm{CO}_{2} \mathrm{H}$ (9:80:10:1 V/V/V/V)

Flow rate: $1 \mathrm{~mL} / \mathrm{min}$.

Column Temperature: Room temperature 
$\lambda_{\max }=257 \mathrm{~nm}, \mathrm{AUFS}=0.001$

Injected volume: $\quad 20 \mu \mathrm{L}$

Sample concentration: $\quad 0.02 \mathrm{mg} / \mathrm{mL}$.

The purity percentages of ampicillin standard powder and other dosage forms manufactured by the two Iranian pharmaceutical companies are given in Table 3.

Table 2. Comparison of purity of ampicillin products by HPLC method

\begin{tabular}{|c|c|c|c|c|c|}
\hline No. & Sample & Manufacturer & $\begin{array}{l}\text { Batch } \\
\text { No. }\end{array}$ & $\begin{array}{c}\text { Purity, } \\
\%\end{array}$ & $\begin{array}{c}\text { Impurity, } \\
\%\end{array}$ \\
\hline 1 & Standard powder & Imported & -- & 100 & 0 \\
\hline 2 & 500 mg Capsules & Farabi & 107 & 100 & 0 \\
\hline 3 & 250 mg Capsules & Farabi & 108 & 100 & 0 \\
\hline 4 & $\begin{array}{l}250 \mathrm{mg} / 5 \mathrm{~mL} \text { Oral } \\
\text { suspension }\end{array}$ & Farabi & 11149 & 100 & 0 \\
\hline 5 & $\begin{array}{l}125 \mathrm{mg} / 5 \mathrm{~mL} \text { Oral } \\
\text { suspension }\end{array}$ & Farabi & 11231 & 100 & 0 \\
\hline 6 & 500 mg Capsules & Kosar & 0107083 & 100 & 0 \\
\hline 7 & 250 mg Capsules & Kosar & 0108214 & 100 & 0 \\
\hline 8 & $\begin{array}{l}250 \mathrm{mg} / 5 \mathrm{~mL} \text { Oral } \\
\text { suspension }\end{array}$ & Kosar & 0103290 & 100 & 0 \\
\hline 9 & $\begin{array}{l}125 \mathrm{mg} / 5 \mathrm{~mL} \text { Oral } \\
\text { suspension }\end{array}$ & Kosar & 0105501 & 100 & 0 \\
\hline 10 & $250 \mathrm{mg}$ Vials & Jaber Ibn Hayan & IB019 & 100 & 0 \\
\hline 11 & $500 \mathrm{mg}$ Vials & Jaber Ibn Hayan & 9K013 & 100 & 0 \\
\hline 12 & $1000 \mathrm{mg}$ Vials & Jaber Ibn Hayan & $0 \mathrm{C} 029$ & 100 & 0 \\
\hline
\end{tabular}

Table 3. Comparison of purity of cloxacillin products by HPLC method

\begin{tabular}{cccccc}
\hline No. & Sample & Manufacturer & $\begin{array}{c}\text { Batch } \\
\text { No. }\end{array}$ & $\begin{array}{c}\text { Purity, } \\
\%\end{array}$ & $\begin{array}{c}\text { Impurity, } \\
\%\end{array}$ \\
\hline 1 & Standard powder & Imported & -- & 100 & 0 \\
2 & $500 \mathrm{mg}$ Capsules & Farabi & 104 & 100 & 0 \\
3 & $250 \mathrm{mg}$ Capsules & Farabi & 109 & 100 & 0 \\
4 & $125 \mathrm{mg} / 5 \mathrm{~mL}$ Oral & Farabi & 793 & 100 & 0 \\
5 & suspension & Kosar & 0104527 & 100 & 0 \\
6 & $250 \mathrm{mg}$ Capsules & Kosar & 0104251 & 100 & 0 \\
7 & $125 \mathrm{mg} / 5 \mathrm{~mL}$ Oral & Kosar & 0104103 & 100 & 0 \\
8 & suspension & Jaber Ibn Hayan & $9 \mathrm{E} 102$ & 100 & 0 \\
9 & $500 \mathrm{mg}$ Vials Vials & Jaber Ibn Hayan & $9 \mathrm{E} 189$ & 100 & 0 \\
\hline
\end{tabular}

\section{Results and Discussion}

Antibiotics are a group of chemical produced by microorganisms and commercially produced synthetically or semi-synthetically. Penicillin is the name f a family of drugs all of which have a common basic structure. The key structural feature of the penicillins is the $\beta$ - lactam ring. The penicillins are differentiatedby the R-group. Also, penicillins are classified as either bacteriocides or bacteriostatics. Because of the wide spread use and therapeutically 
significance of these drugs on the one hand and the fact that the efficacy of a drug depends largely upon the purity of the active ingredient and the excipiants, on the other hand, and also the fact that these medicines and their active ingredients used in this research are purchased and imported from various countries around the world; obviously their qualities may be different from one another to some extent and therefore must be checked regularly; we decided to carry out the following objectives, as with other similar works published by this research group ${ }^{7-11}$, in this research:

(i) Investigating and determining the purity of the standard active ingredients imported from abroad.

(ii) Investigating and determining the purity percentage of the active ingredients in each of the different dosage forms penicillins (Ampicillins, Amoxicillins and Cloxacillins) produced by several Iranian pharmaceutical companies (Kosar, Farabi and Jaber Ibn Hayan).

(iii) Qualitative and quantitative comparisons of the various dosage forms of these drugs.

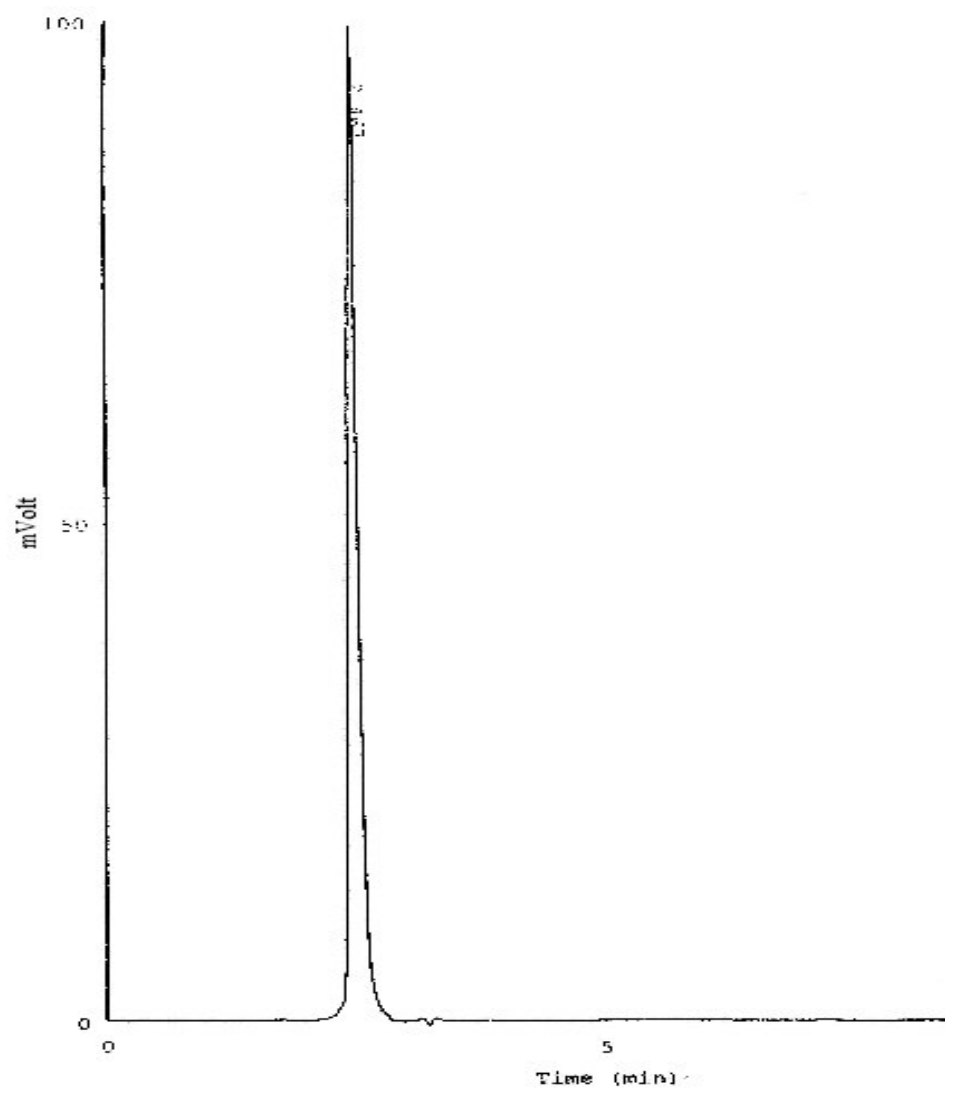

Figure 1. HPLC Chromatogram and data peak report of ampicillin standard powder (active ingredient) imported from abroad.

\begin{tabular}{cccccccccc}
\hline $\begin{array}{c}\text { Ret.Time } \\
\text { min }\end{array}$ & $\begin{array}{c}\text { Start } \\
\text { min }\end{array}$ & $\begin{array}{c}\text { End } \\
\text { min }\end{array}$ & $\begin{array}{c}\text { Height } \\
m V\end{array}$ & $\begin{array}{c}\text { Area } \\
m V^{*} \min \end{array}$ & $\begin{array}{c}\text { Area, } \\
\%\end{array}$ & $\begin{array}{c}\text { Width } \\
\text { min }\end{array}$ & T-factor N-plates & Type \\
\hline 2.467 & 1.87 & 2.97 & 62.16 & 7.4118 & 100 & 0.104 & 1.806 & 3117.3 & BB \\
\hline
\end{tabular}


In order to reach these targets, isocratic reversed phase high performance liquid chromatography (HPLC) with UV-Visible detector which is a rapid and precise technique was employed ${ }^{12}$. Solutions of the standard active ingredients (standard powders), capsules, vials and oral suspension dosage forms of ampicillins, amoxicillins and cloxacillins were made in the appropriate buffer solutions with $1 \mathrm{mg} / \mathrm{mL}, 1 \mathrm{mg} / \mathrm{mL}$ and $0.1 \mathrm{mg} / \mathrm{mL}$ concentrations, respectively, and the $\mathrm{pH}$ was adjusted to $5 \pm 0.1$ for each solution. A $20 \mu \mathrm{L}$ solution from each individual sample and the standard solution were injected separately onto the column of an HPLC instrument which was equipped with ECW 2000 software program of Knauer Company of Germany. $\lambda_{\max }$ of each drug was obtained from its UV-Visible spectrum. On the basis of the chromatograms and the results obtained (Figures 1-4), we concluded that the purity percentages of all standard active ingredients (standard powders), the capsules and oral suspension dosage forms of these drugs imported from abroad and manufactured by Kosar, Farabi and Jaber Ibn Hayan pharmaceutical companies of Iran were all found to be $100 \%$ pure (Tables 1-3).

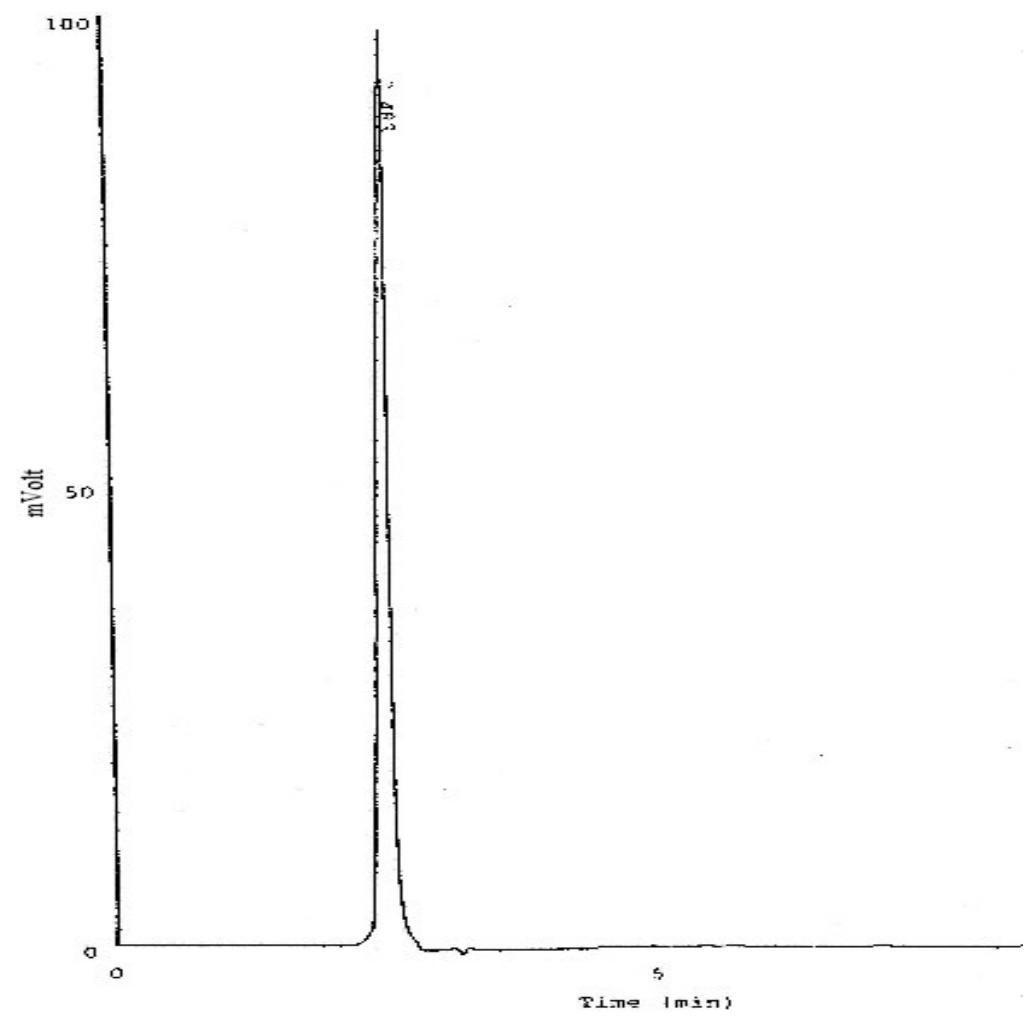

Figure 2. HPLC Chromatogram and data peak report of ampicillin $250 \mathrm{mg}$ capsules manufactured by Kosar Pharmaceutical Co. of Iran.

\begin{tabular}{cccccccccc}
\hline $\begin{array}{c}\text { Ret.Time } \\
\min \end{array}$ & $\begin{array}{c}\text { Start } \\
\min \end{array}$ & $\begin{array}{c}\text { End } \\
\min \end{array}$ & $\begin{array}{c}\text { Height } \\
m V\end{array}$ & $\begin{array}{c}\text { Area } \\
m V^{*} \min \end{array}$ & $\begin{array}{c}\text { Area, } \\
\%\end{array}$ & $\begin{array}{c}\text { Width } \\
\text { min }\end{array}$ & T-factor & N-plates & Type \\
\hline 2.483 & 1.90 & 2.85 & 69.865 & 8.5519 & 100 & 0.107 & 1.598 & 2983.3 & BB \\
\hline
\end{tabular}




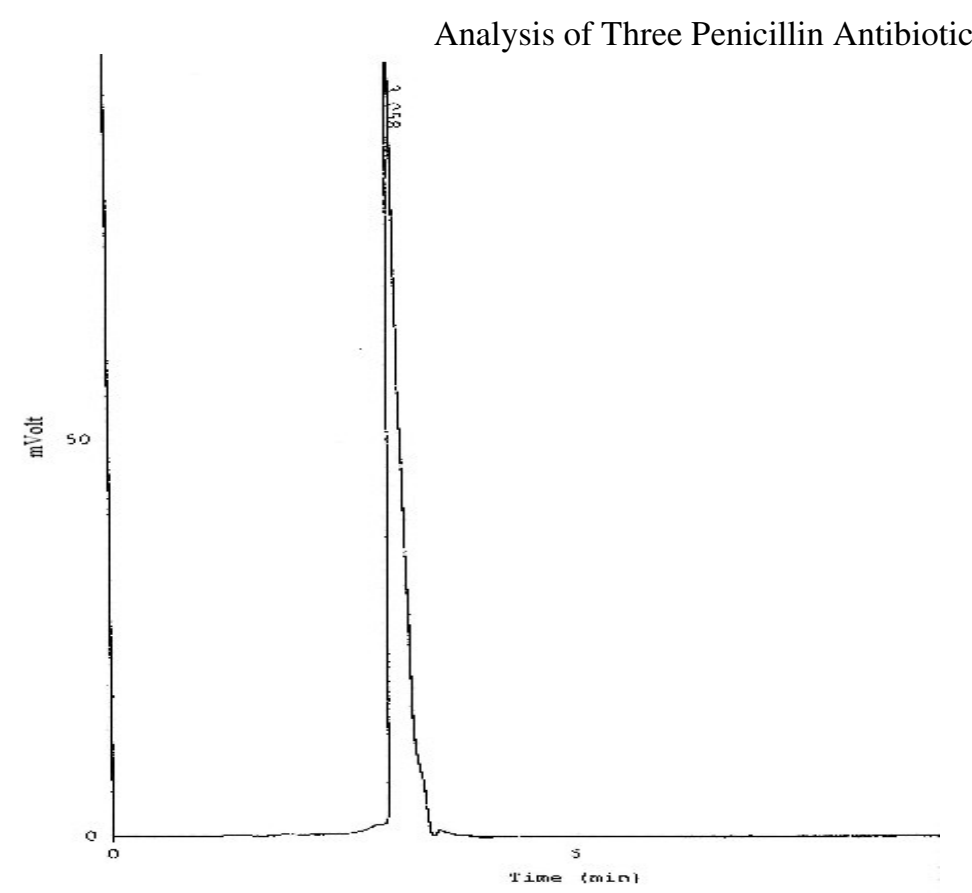

Figure 3. HPLC Chromatogram and data peak report of amoxicillin $250 \mathrm{mg}$ capsules manufactured by Farabi Pharmaceutical Co. of Iran.

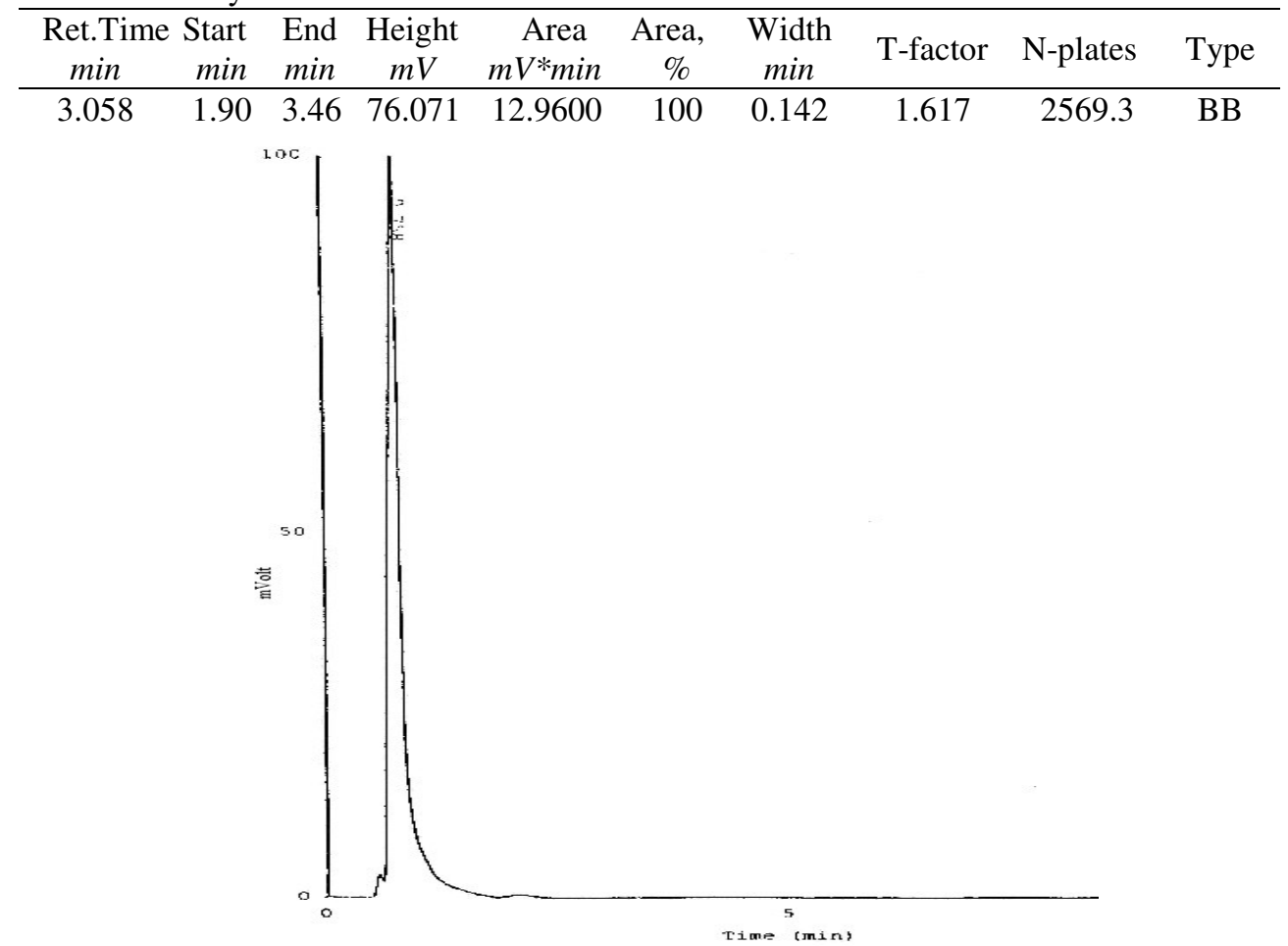

Figure 4. HPLC Chromatogram and data peak report of cloxacillin $250 \mathrm{mg}$ capsules manufactured by Farabi Pharmaceutical Co. of Iran. 


\begin{tabular}{|c|c|c|c|c|c|c|c|c|c|}
\hline $\begin{array}{c}\text { Ret.Time } \\
\text { min }\end{array}$ & $\begin{array}{c}\text { Start } \\
\min \end{array}$ & $\begin{array}{c}\text { End } \\
\min \end{array}$ & $\begin{array}{c}\text { Height } \\
m V\end{array}$ & $\begin{array}{c}\text { Area } \\
m V^{*} \min \end{array}$ & $\begin{array}{c}\text { Area, } \\
\%\end{array}$ & $\begin{array}{c}\text { Width } \\
\min \end{array}$ & T-factor & N-plates & Type \\
\hline 0.758 & 0.62 & 1.26 & 185.625 & 27.2451 & 100 & 0.131 & 1.513 & 185.5 & BB \\
\hline
\end{tabular}

Therefore, it can be concluded and give assurance to patients that all of the various dosage forms of ampicillins, amoxicillins and cloxacillins used in this research and manufactured in Iran have the standard limits acceptable by the internationally well known Pharmacopoeia such as USP ${ }^{13}$ and can satisfy the needs of patients quite well. Also, the imported standard powders were $100 \%$ pure.

\section{References}

1. http://en.wikipedia.org/wiki/Penicillin. Accessed on Dec. $30^{\text {th }}, 2006$.

2. http://en.wikipedia.org/wiki/Ampicillin. Accessed on Dec. $30^{\text {th }}, 2006$.

3. http://www.medicinenet.com/ampicillin/article.htm. Accessed on Dec. $30^{\text {th }}, 2006$.

4. http://www.answers.com/main/ntq-tname-ampicillin-fts_start-

5. http://en.wikipedia.org/wiki/Amoxicillin. Accessed on Dec. $30^{\text {th }}, 2006$.

6. http://en.wikipedia.org/wiki/Cloxacillin. Accessed on Dec. $30^{\text {th }}, 2006$.

7. Ashnagar_A_, Gharib Naseri, N, Fazelian AR and Salimi, A, Int. J. Chem. Sci., 2007, 5 (1), 408-422.

8. Ashnagar A, Gharib Naseri N and Nouruzi V, Biosci. Biotech. Res. Asia, 2007, 4, 29.

9. Ashnagar A, Gharib Naseri N and Kavoosi M, , Asian J. Chem. 2007, 19 (7), 5555.

10. Ashnagar A, Gharib Naseri N and Vosooghi M, Int. J. Chem. Sci., 2007, 5 (1), 297.

11. Ashnagar A, Gharib Naseri N and Hasan pour Bakhtiari, Y, Int. J. Chem. Sci., 2007, 5 (1), 241-255.

12. McMaster M.C., "HPLC, A Practical User's Guide", VCH Publishers, Inc., 1994.

13. USP/NF: the United States Pharmacopoeia/National Formulary. USP $24^{\text {th }} / \mathrm{NF} 19$, New York, Twinbrooke Parkway, 2006, pp 406-408, 437-438, 447-450. 


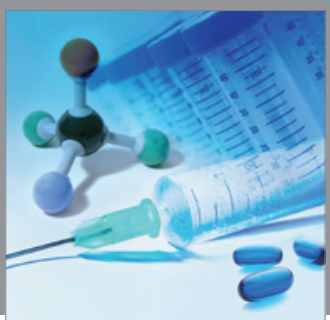

International Journal of

Medicinal Chemistry

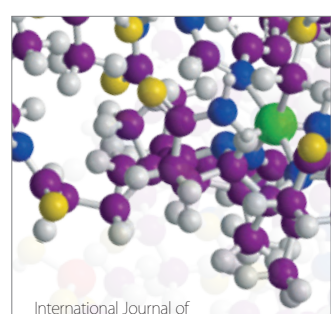

Carbohydrate Chemistry

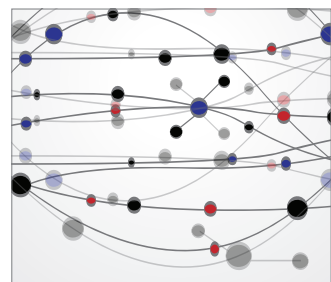

The Scientific World Journal
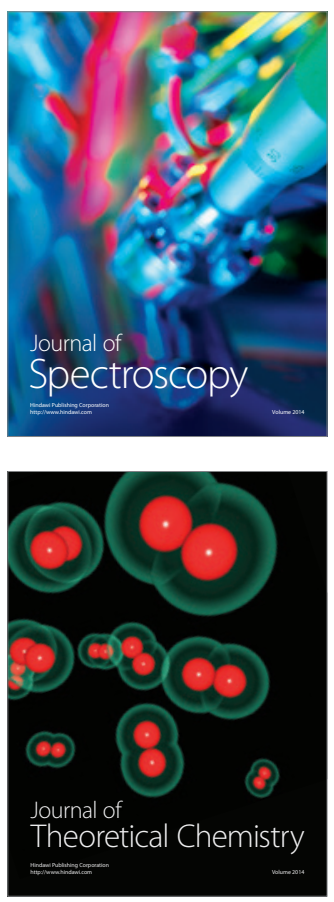
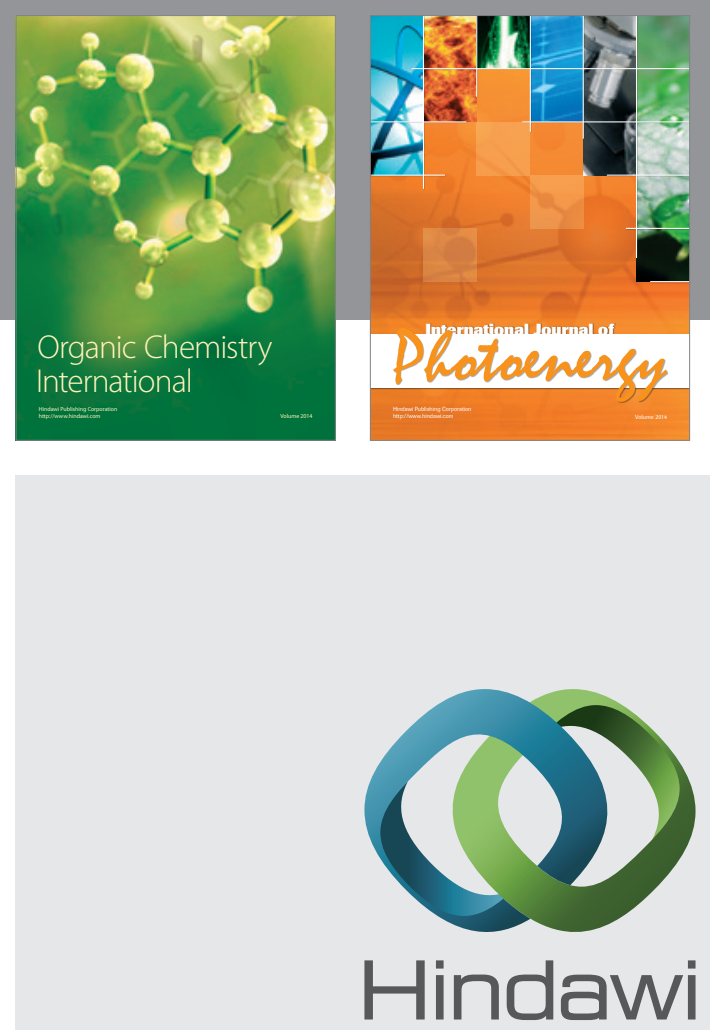

Submit your manuscripts at

http://www.hindawi.com
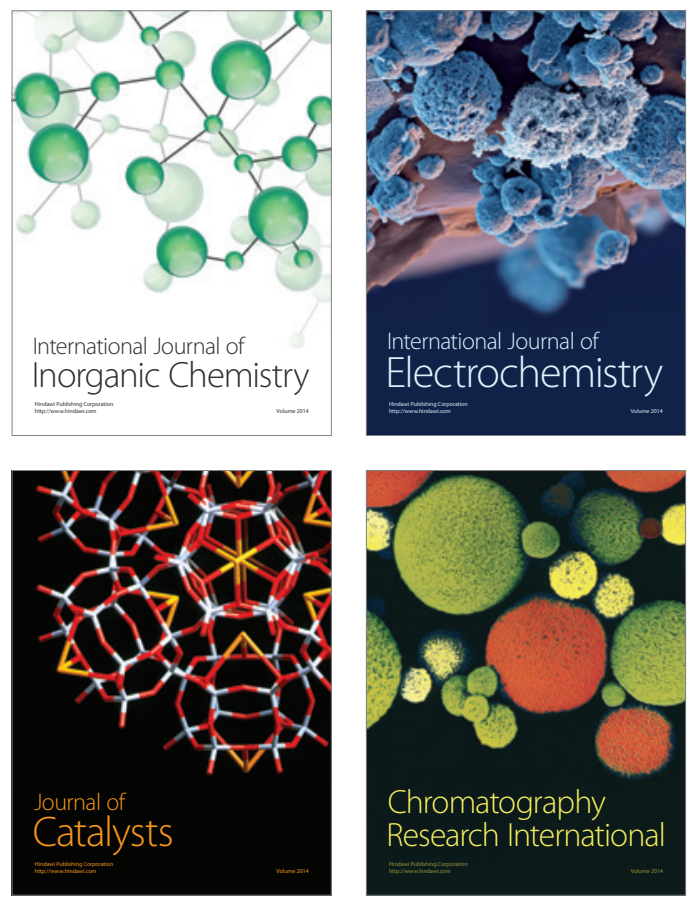
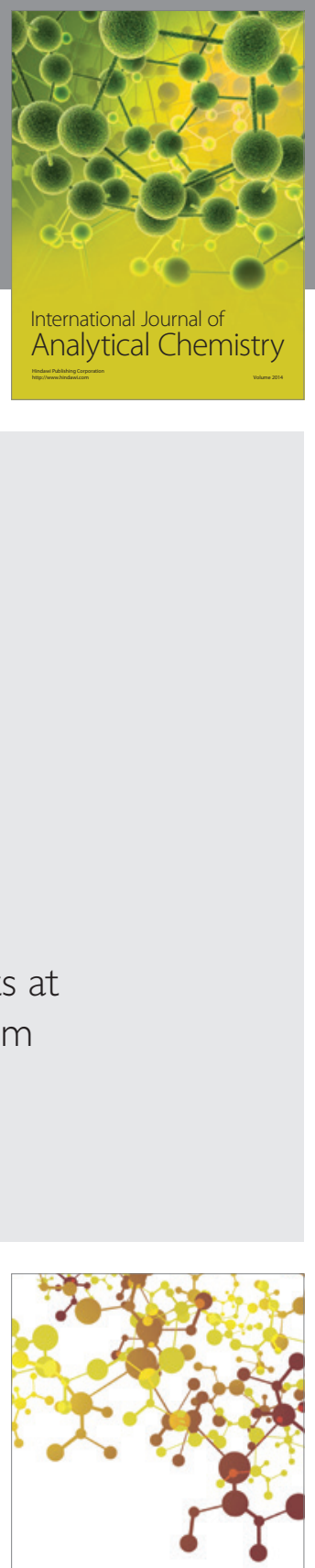

Journal of

Applied Chemistry
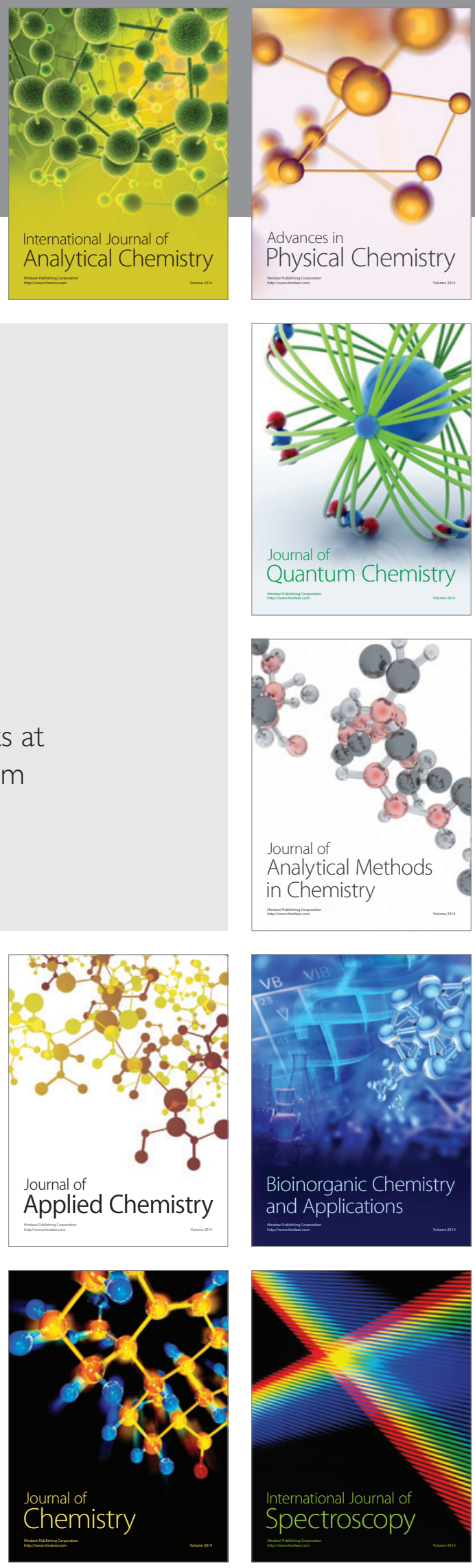